\title{
Contribution of Moringa Tree for Food Security and Management in Southern Ethiopia ; Review
}

\author{
Tsegu Ereso Denbel \\ Lecturer in Agroforestry Department, Collage of Agriculture Science, Bule Hora University \\ P.O.Box 144, Oromia, Ethiopia
}

\begin{abstract}
Consumption of diverse diets, with balanced supplies of macro and micro-nutrients is required for normal human growth and physiological development. However, availability of optimally diverse diets may be constrained by wealth and/or education (including loss of traditional knowledge of indigenous crops. Human diets have been inadvertently simplified in food systems during the Green-Revolution era where agricultural production focused on provision of sufficient energy. In populations depending on cereal-based diets with low nutrient density, dietary simplification and shortage of access to animal source food exacerbates deficiency of vitamins and minerals, also known as hidden hunger. Moringa oleifera and Moringa. stenopetala are underutilized tropical tree species that can play an important role in dietary diversification and contribute to alleviation of hidden hunger in less developed tropical and subtropical countries .In particular, Moringa can be a rich source of some micronutrients that are commonly deficient in cereal-based diets.
\end{abstract}

Keywords: Food, Tree, Moringa, olifera, Stenopetal ,Management

DOI: $10.7176 / \mathrm{JRDM} / 81-03$

Publication date: December $31^{\text {st }} 2021$

\section{Introduction}

Ethiopia is the second-most populous country in Africa next to Nigeria with a fast population growth rate but with huge food deficit gap (Gebreselassie, 2006; Mohammed, Woldeyohannes, Feleke, \& Megabiaw, 2014). The country is the first as the worst of all African countries as nearly 33 million people are suffering from chronic undernourishment and food insecurity (Food \& Agriculture Organization, 2014). Among people suffering from chronic undernourishment, the largest group is rural people with insufficient assets to produce and purchase food (Endalew, Alemu, \& Bizuayehu, 2015). About 33.6\% of the Ethiopian population are living below the poverty line and cannot meet their daily minimum nutritional requirement of 2,200 calories (Godfray et al., 2010). According to the 2014 Central Statistical Agency report, nationally 40\%, 25\%, and $9 \%$ of children under age five were stunted, underweight, and wasted, respectively (Central Statistical Agency, 2014). Protein-energy malnutrition and the various micronutrient deficiency disorders including vitamin A deficiency, nutritional anemias due to iron deficiencies, folic acid and vitamin B12, and iodine deficiency disorders remain important public health problems (Godfray et al., 2010).

Moringa oleifera and MS are the two widely cultivated species of the Moringaceae family, which comprises 13 species. Previous ethnobotanical and biochemical studies in countries where Moringa is grown show that these species are multipurpose Anwar F et,al.2007 and (Gopalakrishnan L, et al. 2016) . Various tissues are used as food, herbal medicine, fodder, hedges, firewood, gum and for water purification (Morton JF,1991 and Mengistu M,et al,.2012) . The foliage, immature pods, seeds, roots and young shoots are used as food and herbal medicine (Popoola JO et al,.2013 and Lim TK,2012) .Moringa stenopetala leaves are used in a similar way as cabbage and spinach and the tree is nicknamed the 'cabbage tree' (Tenaye A,.2009). Fresh MO and MS leaves are either boiled or consumed raw as vegetables, and leaf powders are mixed with other staple foods to increase the mineral, amino acid and vitamin density in the diets. (Anwar F et al,.2007 and Kumssa DB et al.,2017, Popoola JO et al,.2013, Teklehaymanot $\mathrm{T}$ et $\mathrm{al}, 2010$ and Moyo B et al ,.2011)

The aim of this review was to highlighted the Contribution of moringa tree for Food Security and its Management in Southern Ethiopia

\section{Distribution of Moringa tree in Ethiopia}

M. stenopetala was domesticated in the east African lowlands and is indigenous to southern Ethiopia. $M$. stenopetala is often called "cabbage tree" and is an important indigenous vegetable in south western Ethiopia where it is cultivated as a food crop. The Gofa, Konso, Burji, Dherashe, Debub Omo and Gamo communities consume its leaves as a vegetable, especially during the dry season (Abuye and Urga, 2003). M. stenopetala is native to Ethiopia, and it is known by various vernacular names. It is called "Haleko" in Gofa, Gamo and Wolaita areas, "Shelagda" in the Konso language, and "Shiferaw" in Amharic (Engels and Goettsch, 1991; Jahn, 1991). M. stenopetala is particularly important as human food because the leaves, which have high nutritional value appear towards the end of the dry season when few other sources of green vegetables are available. The leaves contain high amounts of essential amino acids and vitamins A and C (Abuye and Urga 2003). 
Despite its significant economic contributions to the livelihood of millions of people in southern

Ethiopia, M. stenopetala has not been given due research and development attention. Thus, there is a need to popularize and promote this important but neglected indigenous vegetable tree.

\section{Role of Moring in Ensuring Food Security and Hunger Alleviation}

In present global context, future of food security is in peril. There are about 30,000 edible plant species present of, only 30 are used to feed the world. As such, food security can only be assured by breaking the monoculture and promotion of neglected and underutilized crop species.

Food security is defined as achieving food security at the individual, household, national, regional and global levels when all people, at all times, have physical and economic access to sufficient, safe and nutritious food to meet their dietary needs and food preferences for an active and healthy life" (FAO 1996).The absolute number of undernourished people, i.e. those facing chronic food deprivation, has increased to nearly 821 million in 2017 , from around 804 million in 2016 (FAO 2018). It is evident that among diverse availability of food crops, our world is dependent upon only few major crops and cereals; which have raised the issue of crop diversification.

Despite their nutritious edible parts, Moringa spp. are sometimes classified as ${ }^{\text {afamine food }}{ }^{\circ}$, consumed by humans at times of food scarcity(Lockett CT, Calvert CC and Grivetti LE ,2000 and Sena LP,1998). Similarly, preliminary information indicates that the human dietary usage of the edible parts of these species is limited. For example, in southern Ethiopia (S. ETH), Moringa tends to be cultivated by communities living in marginal environments, with small land holdings due to high population density [6]. In these areas, there is often a reliance on rain-fed agriculture as a source of livelihood and there are frequent food crop failures due to drought (Jiru D et al,.2000. The use of indigenous and locally available vegetables such as Moringa as a human food is often linked with low social class status in many communities in Africa and Asia Ebert AW,2014 and Cernansky R. 2015).

In order to secure the future from food availability and nutrition, Moringa can be an effective crop species. Fresh Moringa leaves can be eaten raw, if they're very young and tender, but can be cooked as vegetable. Similarly, as a way to preserve nutrients leaf powder can also be made; this can be consumed as a whole food or added to other cooked food. Likewise, Moringa pod can be boiled, steamed, fried and eaten when they are young and tender and the seeds can also be consumed like other peas. It is also used in fortification of bread, biscuit, yoghurt, cheese, soup etc. (Oyeyinka \& Oyeyinka 2016). The inclusion of Moringa flower, seed or leaf powder in bread preparation has been reported to improve the nutritional value of bread (Chinma et al. 2012).

All Moring Growing Household s had used Moring Stenopetala as a source of food (Fig 1), with some also as a source of food and income (42\%), as a source of food, income and drink (29\%), and as source of food, drink and medicine (21\%). Moringa growing households consumed boiled fresh leaves at a frequency of three times a day $(92 \%)$ and most days in a week $(8 \%)$. The quantity of leaves consumed per day were two big and medium bunches (4\% each), one big bunch (42\%), one medium bunch $(29 \%)$ and one small bunch (21\%). Other forms of consumption of Moring Stenopetala

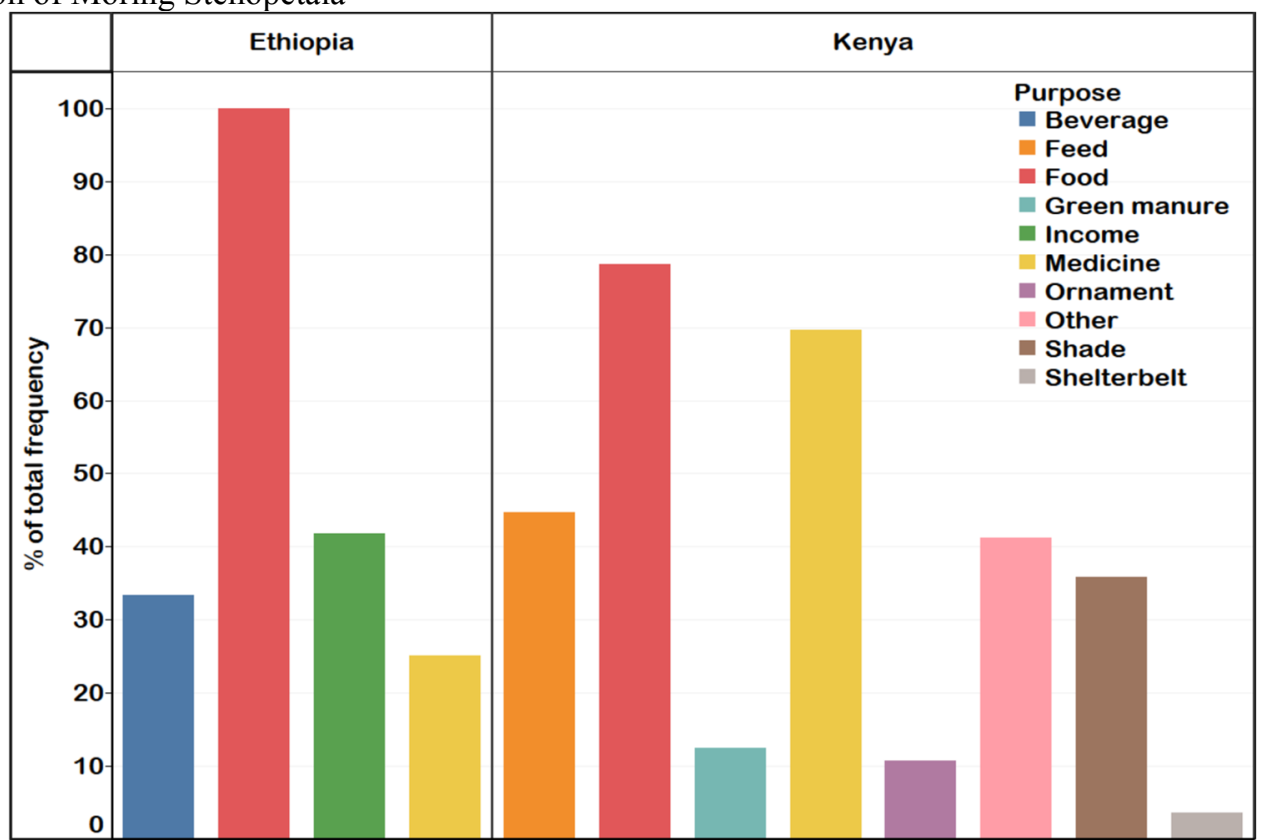

Fig 1. Purposes for which Moringa was grown in southern Ethiopia and Kenya. Number of respondents: southern Ethiopia $(\mathrm{n}=24)$ and Kenya $(\mathrm{n}=56)$.

Source; https://doi.org/10.1371/journal.pone.0187651.g002 


\section{Food and Nutritional Value of Moringa}

Moringa contains much more nutrient and medicinal chemical, and so, it is named as miracle tree plant. Moringa leaves contain more vitamin A than carrots, more Vitamin $\mathrm{C}$ than orange, more potassium than bananas, and on top of that the protein quality of Moringa leaves competes with that of milk and eggs (Fahey 2005). Moringa tree is rich in nutrients such as minerals, fiber and proteins that can play essential role in human nutritional consumption. Numerous of the research reports have shown that Moringa oleifera leaves has high protein compared to with other leaves eaten as food (Suchada, Supawan, \& Thanapat 2010). Each part of the Moringa tree (fruits, seeds, leaves, flowers, barks and roots) is associated with the presence of at least one, or in most number of benefits (Zaku et al. 2015). It have multiple uses i.e. leaves can be eaten fresh, cooked, or stored as dried powder for many months without loss of nutritional value. Till date, Moringa has seven use categories identified namely, medicine, food, fodder, fencing, firewood, coagulant and gum (Popoola \& Obembe 2013). Each part of the Moringa tree (fruits, seeds, leaves, flowers, bark and roots) is associated with the presence of at least one, or in most number of benefits (Zaku et al. 2015). The analysis of dietary iron supplements in the liver influenced by M. oleifera leaves revealed that iron from Moringa can overcome iron deficiency (Saini et al. 2014).

Table 1: Comparison of Moringa fresh and dry leaves with common foods per 100 grams

\begin{tabular}{|l|l|l|l|}
\hline \multirow{2}{*}{ Nutrient } & \multirow{2}{*}{ Common foods } & \multicolumn{2}{l|}{ Moringa leaves } \\
\cline { 3 - 4 } & & Fresh leaves & \multicolumn{1}{c|}{ Dried leaves } \\
\hline Vitamin A & $1.8 \mathrm{mg}$ Carrots & $6.8 \mathrm{mg}$ & $18.9 \mathrm{mg}$ \\
\hline Calcium & $120 \mathrm{mg}$ Milk & $440 \mathrm{mg}$ & $2003 \mathrm{mg}$ \\
\hline Potassium & $88 \mathrm{mg}$ Banana & $259 \mathrm{mg}$ & $1324 \mathrm{mg}$ \\
\hline Protein & $3.1 \mathrm{~g}$ Yogurt & $6.7 \mathrm{mg}$ & $27.1 \mathrm{~g}$ \\
\hline Vitamin C & $30 \mathrm{mg}$ Orange & $220 \mathrm{mg}$ & $17.3 \mathrm{mg}$ \\
\hline
\end{tabular}

Source: Chukwuebuka 2015

Besides, it has great use in culinary purpose. Wide varieties of dishes can be prepared from the parts of moringa, as a whole or mixed. In south Indian varieties, culinary items like sambars and fries are prepared from moringa pod. Likewise, it is used in curries, kormas and dal to enhance the taste; and at some place it is reported to be used in preparing cutlet dishes (Paliwa et al. 2011).

\subsection{Medicinal Use}

According to Endeshaw (2003), the leaves, roots, and seeds of M. stenopetala and M. oleifera have a long tradition of use in folk medicine. Various parts of the M. stenopetala tree are claimed to contain disease-preventing chemicals. People with high blood pressure boil the leaves and drink the water to get relief from their aliment. Gebreselassie et al., (2011) suggested that leaf extracts of M. stenopetala are used to lower blood glucose and cholesterol levels. They reported that aqueous leaf extract of M. stenopetala is shown to increase body weight and reduce serum glucose and cholesterol levels in mice. Serum glucose and serum cholesterol levels decreased significantly after six weeks of treatment. They indicated the need for further studies in order to fractionate the active principle and find out the mechanism(s) of action of M. stenopetala leaf extract on blood glucose and cholesterol levels in animal models to ascertain its therapeutic importance. Similarly, experiments conducted on animal models showed that butanol fraction of the ethanol extract of M. stenopetala leaves has anti-hyperglycemic and anti-hyper lipedemic effects, and as a result, can be used to treat diabetes (Alemayehu et al., 2012). These researchers indicated that administration of butanol fraction of ethanol extract of $\mathrm{M}$. stenopetala leaves to diabetic mice resulted in significant reduction of fasting blood glucose level, serum total cholesterol, and triglyceride levels. The fraction also showed a tendency to improve body weight gain in diabetic mice

According to Yalemtsehay (2003), there are claims that the leaves of M. stenopetala boiled in water can cure malaria, hypertension, and stomach pain. The roots of $\mathrm{M}$. stenopetala chopped and mixed with water are also used for treating severe cases of malaria (Yalemtsehay,2003).. A recent report by Kinuthia et al., (2013) showed that methanolic extracts of dried leaves of M. stenopetala exhibit antileishmanial activity. According to these individuals, traditionally, M. stenopetala leaves are used to expel retained placenta from women and cows; and the Turkana of northern Kenya make an infusion with the leaves of M. stenopetala as a remedy against leprosy The Njemps people of Kenya chew the bark of M. stenopetala as a treatment against cough and use the bark extracts to make fortifying soup (Demeulenaere, 2001). In Somalia, women inhale the smoke released by the burning of the M. stenopetala root during difficult labour (Demeulenaere, 2001).

Moringa is really a miracle plant that has wide range of medicinal uses. Moringa plant have several specific remedial properties including its anti-fibrotic, anti-inflammatory, anti-microbial, anti-hypoglycemic, anti-oxidant, anti-tumor and anti-cancer properties (Razis et al. 2014). Practically, most parts of the Moringa tree are utilized for some medicinal use which is presented. Moringa has been used in the traditional medicine passed down for 
centuries in many cultures around the word, for skin infections, anemia, anxiety, asthma, blackheads, blood impurities, bronchitis, catarrh, chest congestion, cholera, conjunctivitis, cough, diarrhea, eye and ear infections, fever, glandular, swelling, headaches, abnormal blood pressure, hysteria, pain in joints, pimples, psoriasis, respiratory disorders, scurvy, semen deficiency, sore throat, sprain, tuberculosis, for intestinal worms, lactation, diabetes and pregnancy (Nikkon et al 2003).

\subsection{Water purification}

According to Göttsch (1984) dried and crushed seeds of the plant are important to clarify muddy and turbid water, to suit it for drinking analogous to the chemical coagulant Aluminum sulphate Göttsch (1984), .has also further proved that it lowers the concentration of bacteria (it has bactericidal effect) and fungi (it has fungicidal effect). Eilert et al. (1981) have also reported that water purification and its bactericidal and fungicidal effect over weigh that of M. oleifera. However, the local people in Ethiopia do not use the plant for water clarification (Göttsch, 1984). Göttsch (1984) further added that only the roots of Maerua subcordata (Amharic: Wuha matariya) is used for water purification by people living on both sides of the lower Omo river in Gamo Gofa, South-West Ethiopia. Unfortunately, this species is toxic and not very efficient coagulant but it is on use elsewhere in Africa (Jahn, 1991). Whereas, water purified using crushed seeds of M. oleifera and M. stenopetala is safe for human consumption (Berger et al.,1984). Most Ethiopians living in rural areas are dependent on surface water, and this situation is not likely to change in the near future. Even if locally treated water is not perfect hygienically, at least it would be important to have safe water by clarifying it with cheap and easily accessible method. Therefore, the seeds have potential for water purification

\section{Moring Tree management.}

It has been reported that $M$. stenopetala grows wild at elevations between 1,000 and 1,800 m (Mark, 1998) but it will grow as high as $2200 \mathrm{~m}$ and as low as $300 \mathrm{~m}$. Studies show that light frosts will do it no harm and freezes, though, may cause it to die back to ground level, where new sprouts may be produced. Full sun is normal, though partial shade is tolerated. It is resistant to dry weather. Optimum light for germination of all Moringa species is half shade (Ethiopian Tree Fund Foundation, 2006). The most striking characteristic of the Konso agricultural system is the cultivation of the cabbage tree (M. stenopetala). The tree is densely planted within the villages and generally more widely spaced in the fields and terraces between 1600 and $1800 \mathrm{~m}$. Its light green leaves and the conspicuous grey bark are characteristic features of the cabbage tree. Konso can be considered as the area where the tree was first cultivated. From here the cultivation has spread into neighboring areas where it is being used intensively as well (Engels, 1991). Seeds should be planted about $2 \mathrm{~cm}$ deep in soil that is moist but not too wet. Sprouting occurs normally in 1-2 weeks. It can be allowed to grow for shade (6-15 m), or kept low (about 1-1.5 $\mathrm{m}$ ) for easier harvesting. M. stenopetala quickly produces a large gray trunk and leaves covered with glistening nectars. It quickly sends out new growth from the trunk when cut, or from the ground when frozen. Living fences can be continually cut back to a few feet. It is an extremely fast-growing tree and continued to grow during the exceptionally long dry season (Ethiopian Tree Fund Foundation, 2006).

\section{Conclusion}

Moringa oleifera $L$. is a plant native to India but it is widely grown tree in Africa, Pacific Islands, Caribbean, Philippines, South Africa, Asia, Florida and Latin America. It is a drought-tolerant, fast-growing, multi-purpose, eco- friendly and one of most useful tree due to its medicinal and nutritional properties in world and therefore described as a 'miracle tree'. Moringa tree is rich in nutrients such as vitamins, minerals, fiber and proteins that. It is a very nutritious plant containing more vitamin A than carrots, more Vitamin $\mathrm{C}$ than orange, more potassium than bananas, and protein quality of leaves competing with that of milk and eggs. Hence, it can play essential role in human nutritional consumption. Moringa has wide range of medicinal uses as anti-fibrotic, anti-inflammatory, anti-microbial, anti-hypoglycemic, anti-oxidant, anti-tumor and anti-cancer properties. Fresh Moringa leaves can be used in vegetables. Leaf powder can also be consumed as food, nutrient supplement and medicinal purpose. The tender pods can be consumed as boiled, steamed, and fried and the seeds can also be consumed like peas. Moringa can be effective in assuring food security be by breaking the monoculture and also promote promotion of other neglected and underutilized crop species. Moringa can be used as a good source of animal and bird feeds due to its nutritional quality and better bio-mass production especially in dry periods. Similarly, its leaf extract was found to improve fruit set, yield, fruit weight, firmness, color, soluble solids content, vitamin C, anthocyanin content and antioxidant activity. Thus, Self-reinforcing nature of Moringa from less potential soil and its extract replenishing the nutrient is beneficial in agricultural land.

\section{Reference}

Abuye, C., Urga, K. (2003). “A compositional study of Moringa stenopetala leaves”, East African Medical Journal, Vol. 80:247-252 
Alemayehu Toma, Eyasu Makonnen, Asfaw Debella, and Brehanu Tesfaye. (2012). "Antihyperglycemic effect on chronic administration of butanol fraction of ethanol extract of Moringa stenopetela leaves in alloxan induced diabetic mice", Asian Pacific Journal of Tropical Biomedicine, Vol. 2 No. 3, Supplement, pp. S1606-S1610 and sulphur in Africa: improving nutrition with Moringa oleifera. Afr J Food Agric Nutr Dev. 2015; 15(1).

Anwar F, Latif S, Ashraf M, Gilani AH. Moringa oleifera: a food plant with multiple medicinal uses. Phytother Res. 2007; 21(1): 17 \pm 25 . https://doi.org/10.1002/ptr.2023 PMID: 17089328

Berger, M.R., Habs, M., Jahn, SAA. and Schmahl, D. (1984). Toxicological Assessment of seeds from Moringa oleifera and Moringa stenopetala for domestic water treatment of tropical raw waters. East Afri. Med. J. 16: $712-715$

Bezuneh, T. (2010). Technological challenges of sustainable enset farming system: For enhancing the production of food/fiber and industrial outputs. In Proceedings of Enset Research and Development Experiences in Ethiopia: National Workshop: 19-20 August 2010; Wolkite, Ethiopia (pp. 1-21).

Central Statistical Agency. (2014). Ethiopia mini demographic and health survey 2014. Addis Ababa, Ethiopia: Ethiopian Statistical Agency. Retrieved from https ://phe-ethio pia.org/admin/ uploa ds/attac hment-1939Ethio pia_Mini_Demog raphic_and_Health_nSurvey_2014-2.pdf

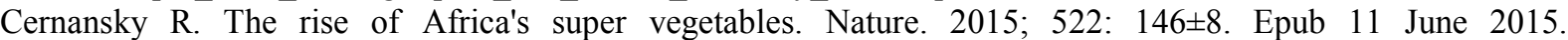
https://doi.org/10.1038/522146a PMID: 26062494

Chinma CE, Abu JO \&Akoma JN. 2012. Effect of germinated Moringa and Tigernut flour blends on the quality of wheat-based bread.Journal of food processing and preservation.

Chukwuebuka E. 2015. Moringaoleifera“The Mother's Best Friend". International Journal of Nutrition and Food Sciences, pp. Vol: 4, No: 6, Page:624-630.concentration of Moringa oleifera Lam. and M. stenopetala (Bak. f.) Cuf.: Role in human nutrition. PLOS

Demeulenaere, E. (2001). "Moringa stenopetala, a subsistence resource in the Konso district", paper presented to the scientific meeting on development potential for Moringa products, Dar es Salaam, Tanzania, 29 October2 November 2001

Ebert AW. Potential of underutilized traditional vegetables and legume crops to contribute to food and nutritional security, income and more sustainable production systems. Sustainability. 2014; 6(1): $319 \pm 35$. https://doi.org/10.3390/su6010319

Eilert, U., Wolters, B. and Nahrstedt, A. (1981). The Antibiotic principle of seeds of Moringa oleifera and Moringa stenopetala. Planta Med. 42:55-61

Endalew, B., Alemu, G. T., \& Bizuayehu, S. (2015). State of household food insecurity in Ethiopia. Journal of Radix International Educational and Research Consortium, 4(12), 1-14.

Endeshaw Haile. (2003). "Promoting the miracle tree of hope", Ethiopian Herald, 19 July 2003.

Engels, H. (1991). Konso agriculture and its plant genetic resources. Cambridge University Press. Cambridge, United Kingdom. pp. 169-186.

Ethiopian Tree Fund Foundation. (2006). Retrieved January (2016), from http://www.etff.org

Fahey J. 2005. Moringa oleifera: A review of the medical evidence for its nutritional, therapeutic and prophylactic properties. Trees for Life Journal, p. 1: 5.

FAO. 1996. Rome declaration on world food security and world food. Rome, Food and Agriculture Organization of United Nations

FAO. 2018. The State of Food Security and Nutrition in the World: Building climate resilience for food security and nutrition, Rome: Food and Agriculture Organization of United nations.

Gebreselassie Desta and Yalemtsehay Mekonnen. (2011). The effects of Moringa stenopetala on blood Parameters and histopathology of liver and kidney in mice. Ethiop. J.Health Dev, 25, 51-57.

Godfray, H. C. J., Beddington, J. R., Crute, I. R., Haddad, L., Lawrence, D., Muir, J. F., ... Toulmin, C. (2010). Food security: The challenge of feeding 9 billion people. Science, 327, 812 818. https ://doi.org/10.1126/ scien ce. 1185383

Gopalakrishnan L, Doriya K, Kumar DS. Moringa oleifera: A review on nutritive importance and its medicinal application. Food Sci Hum Wellness. 2016; 5(2): 49 \pm 56 . https://doi.org/https://doi.org/10. 1016/j.fshw.2016.04.001

Göttsch, E. (1984). Water-clarifying plants in Ethiopia. Ethiopia Medical Journal 22: 219 - 220.

Int. 2017; 33(1): 1 \pm 21 . https://doi.org/10.1080/87559129.2015.1137309

Jahn, SAA. (1991). The traditional Domestication of a multipurpose tree Moringa stenopetala (Bak.f.) Cuf. in the Ethiopia Rift valley. $A M B I O$ 20: 244-247.

Jiru D, Sonder K, Alemayehu L, Mekonen Y, Anjulo A, editors. Leaf yield and nutritive value of Moringa stenopetala and Moringa oleifera accessions: Its potential role in food security in constrained dry farming agroforestry system. Proceedings of the Moringa and other highly nutritious plant resources: Strategies, standards and markets for a better impact on nutrition in Africa, Accra, Ghana; 2006; $\mathrm{p} 16 \pm 18$.

Kinuthia, G. K., Kabiru,E. W., Anjili C. O., Nicholas K., Kigondu E. M., Ngure V. N., Ingonga J. M. and Gikonyo 
N. K. (2013). "Efficacy of crude methanolic extracts of Allium sativum L. 42 and Moringa stenopetala (Baker f.) Cufod. against Leishmania major”, International Journal of Medicinal and Aromatic Plant 4:1625

Kumssa DB, Joy EJM, Young SD, Odee DW, Ander EL, Broadley MR. Variation in the mineral element

Lim TK. Moringa oleifera. Edible medicinal and non medicinal plants. 3: Springer Netherlands; 2012. p. $453 \pm 85$.

Lockett CT, Calvert CC, Grivetti LE. Energy and micronutrient composition of dietary and medicinal wild plants consumed during drought. Study of rural Fulani, Northeastern Nigeria. Int J Food Sci Nutr. 2000; 51(3): 195 \pm 208 . PMID: 10945116

Lyons G, Gondwe C, Banuelos G, Mendoza MCZ, Haug A, Christophersen OA. Drumming up selenium

Mengistu M, Abebe Y, Mekonnen Y, Tolessa T. In vivo and in vitro hypotensive effect of aqueous extract of Moringa stenopetala. Afr Health Sci. 2012; 12(4): 545 \pm 51 . https://doi.org/10.4314/ahs.v12i4.23. PMID: 23515422

Miller DD, Welch RM. Food system strategies for preventing micronutrient malnutrition. Food Policy. 2013; 42(0): 115 \pm 28 . https://doi.org/10.1016/j.foodpol.2013.06.008

Mohammed, A., Woldeyohannes, D., Feleke, A., \& Megabiaw, B. (2014). Determinants of modern contraceptive utilization among married women of reproductive age group in North Shoa Zone, Amhara Region, Ethiopia. Reproductive Health, 11(1), 13. https ://doi. org/10.1186/1742-4755-11-13

Morton JF. The horseradish tree, Moringa pterygosperma (Moringaceae)Đa boon to arid lands? Econ Bot. 1991; 45(3): 318 \pm 33 . https://doi.org/10.1007/bf02887070

Moyo B, Masika PJ, Hugo A, Muchenje V. Nutritional characterization of Moringa (Moringa oleifera Lam.) leaves. Afr J Biotechnol. 2011; 10(60): 12925 \pm 33 .

Nikkon, F, Saud ZA, Rahman MH \&Haque ME. 2003. In vitro antimicrobial activity of the compound isolated from chloroform extract of Moringa oleifera Lam. Pak. J. Biol. Sci., pp. 6: 1888-1890.

ONE. 2017; 12(4): e0175503. https://doi.org/10.1371/journal.pone.0175503 PMID: 28388674

Oyeyinka AT \&Oyeyinka SA. 2016. Moringa oleifera as a food fortificant: Recent trends and prospects. Journal of Saudi Society of Agricultural Science, pp. 127-136

Paliwal R, Sharma V \&Pracheta .2011. A Review on Horse Radish Tree (Moringa oleifera): A Multipurpose Tree with High Economic and Commercial Importance. Asian J. of Biotech, Vol.3(4) pp317-328

Pingali PL. Green Revolution: Impacts, limits, and the path ahead. Proc Natl Acad Sci USA 2012; 109 (31): 12302 \pm 8 . https://doi.org/10.1073/pnas.0912953109 PMID: 22826253

Popoola JO, Obembe OO. Local knowledge, use pattern and geographical distribution of Moringa oleifera Lam. (Moringaceae) in Nigeria. J Ethnopharmacol. 2013; 150(2): 682 \pm 91 . https://doi.org/10.1016/ j.jep.2013.09.043 PMID: 24096203

Popoola JO, Obembe OO. Local knowledge, use pattern and geographical distribution of Moringa oleifera Lam. (Moringaceae) in Nigeria. J Ethnopharmacol. 2013; 150(2): 682 \pm 91 . https://doi.org/10.1016/ j.jep.2013.09.043 PMID: 24096203

Razis AFA, Ibrahim MD \&Kntayya SB. 2014. Health Benefits of Moringaoleifera. Asian Pacific journal of cancer prevention: APJCP, pp. 15(20):8571-6.

Sena LP, Vanderjagt DJ, Rivera C, Tsin ATC, Muhamadu I, Mahamadou O, et al. Analysis of nutritional

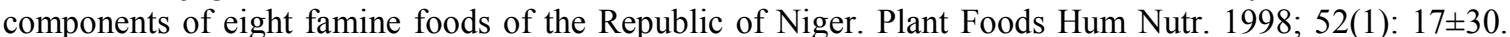
https://doi.org/10.1023/a:1008010009170 PMID: 9839831

Sharma P, Aggarwal P, Kaur A. Biofortification: A new approach to eradicate hidden hunger. Food Rev

Sinha RK et al. 2009. Bioremediation of contaminated sites: a low-cost nature's biotechnology for environmental clean up by versatile microbes, plants \& earthworms. In: solid waste management and environmental remediation. New York: Nova Science Publishers, Inc.

Stevens CO, Ugese FD, Baiyeri KP. Utilization potentials of Moringa oleifera in Nigeria: a preliminary assessment

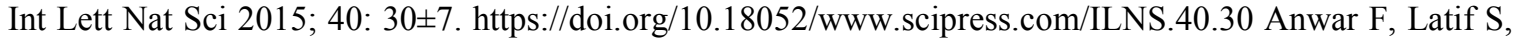
Ashraf M, Gilani AH. Moringa oleifera: a food plant with multiple medicinal uses. Phytother Res. 2007; 21(1): 17 \pm 25 . https://doi.org/10.1002/ptr.2023 PMID: 17089328

Suchada J, Supawan B \&Thanapat S. 2010. Nutrients and Minerals Content of Eleven Different Samples of MoringaOleifera Cultivated in Thialand. J Health RES, p. 24: 123-127.

Teklehaymanot T, Giday M. Ethnobotanical study of wild edible plants of Kara and Kwego semi-pastoralist people in Lower Omo River Valley, Debub Omo Zone, SNNPR, Ethiopia. J Ethnobiol Ethnomed. 2010; 6(1): 23. https://doi.org/10.1186/1746-4269-6-23 PMID: 20712910

Tenaye A, Geta E, Hebana E. A multipurpose cabbage tree (Moringa stenopetala): production, utilization and marketing in SNNPR, Ethiopia. In: Jaenicke H, Ganry J, HoeschleZeledon I, Kahane R, editors. International Symposium on Underutilized Plants for Food Security, Nutrition, Income and Sustainable Development. Acta Horticulturae. 8062009. p. $115 \pm 20$.

Welch RM, Graham RD. A new paradigm for world agriculture: meeting human needs: productive, sustainable, 


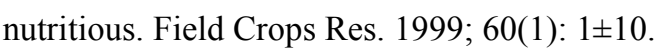

Yalemtsehay Mekonnen (2003). "The multi-purpose Moringa tree: Ethiopia", Available at: http://tc dc.undp.org/sie/experiences/vol10/V10_S3_MoringaTree.pdf

Zaku SG, Tukur S \& Kabir A. 2015. Moringa oleifera: An underutilized tree in Nigeria with amazing versatility. African Journal of Food Science, pp. 9(9) 456-461. 